\title{
High-Dose Chemotherapy and Autologous Stem Cell Transplantation in Breast Cancer: Is There Still a Hope?
}

\author{
Taner DEMIRER \\ Ankara University, Faculty of Medicine, Dept of Hematology, Ankara, TURKEY
}

\begin{abstract}
The prognosis of high-risk breast cancer (HRBC) patients has changed very little in the past two decades with the use of conventional chemotherapy and even with the addition of monoclonal therapies. High-Dose Chemotherapy (HDC) with autologous stem cells transplantation (ASCT) is today seen as a safe treatment modality with low toxicity, and in fact phase II studies suggested that this approach improved long-term disease-control. Unfortunately, results of meta-analysis from randomized studies did not showed an overall survival benefit thus, the efficacy of HDC and ASCT for HRBC has been an area of intense controversy among the medical oncology community. The conclusion of the meta-analysis may further raise the question among the scientific community whether HDC with ASCT in high-risk primary breast cancer (BC) should continue to be explored or abandoned owing to a lack of definite overall survival (OS) benefit. Nevertheless, HDC might be of potential benefit in some subgroups of HRBC patients and we will focus on this issue in this concise review.
\end{abstract}

Keywords: Breast cancer, High dose chemotherapy, Stem cell transplantation, Adjuvant, Metastatic disease

\section{ÖZET}

\section{Meme Kanserinde Yüksek Doz Kemoterapi ve Otolog Kök Hücre Transplantasyonu: Hala bir Ümit Var mı?}

Son 2 dekatta yeni konvansiyonel tedavilere ve monoklonal antikorlara rağmen yüksek riskli meme kanserlerinin prognozu çok değişmemiştir. Bugün meme kanserlerinde yüksek doz kemoterapi (YDK) ve otolog kök hücre transplantasyonunun (OPKHT) toksisi- tesi çok düşük olup bir çok faz-II çalışmada yaşam oranlarında artış gösterilmiştir. Ancak yapılan meta-analiz çalışmalarının sonuçları YDK ve OPKHT nın yüksek riskli ve metastatik meme kanserlerinde konvansiyonel tedaviye kıyasla genelde yaşam oranları yönünden bir üstünlüğünü gösterememiştir. Bu sonuçlar medikal onkologlar arasında geniş tartışmalara ve hatta bazı tereddütlere sebep olmuştur. Meta-analiz sonuçları baz alınarak bu konuda daha ileri çalışmalara devam edilmesi ile genelde yaşam oranlarında bir üstünlüğün gösterilememesi nedeni ile bu tedavi yönteminin artık kullanılmaması görüşleri arasında medikal onkoloji camiasında bir ikilem ortaya çıkmışır. Ancak yine de yüksek riskli meme kanserlerinin bazı alt gruplarının YDK ve OPKHT tedavisinden fayda görebileceğine dair literatürde veriler mevcut olması nedeni ile bu derleme makalede bu konuya yakından odaklanacağız.

Anahtar Kelimeler: Meme kanseri, Yüksek doz kemoterapi, Kök hücre transplantasyonu, Adjuvan, Metastatik hastallık 


\section{INTRODUCTION}

The journey to personalized breast cancer (BC) care, based on molecular tumor characteristics, is still long in the majority of patients as cytotoxic chemotherapy $(\mathrm{CT})$ remains a pivotal therapeutic approach in operable and advanced disease. The clinical correlation between dose-intensity of CT, that can be achieved by either increasing the single dose per cycle (ie, higher dose) or by reducing the intervals between cycles (ie, dose density), and outcome in $\mathrm{BC}$ has been described since the eighties ${ }^{1-3}$ leading to the premature acceptance of high-dose chemotherapy (HDC) with autologous stem cells transplantation (ASCT) as a treatment option both in the adjuvant setting and for metastatic disease, with up to nearly 2,000 patients per year undergoing this procedure in the mid-nineties in Europe..$^{4-8}$ Unfortunately, the vast majority of patients were treated outside prospective randomized studies.

Allogeneic stem cell transplantation has also been used as an innovative approach for treatment of advanced breast cancers. EBMT (European Group for Blood and Marrow Transplantation) Solid Tumor Working Group showed the presence of graftversus-tumor effect in a phase-I and several phaseII studies in patients with solid tumors including BC. ${ }^{8-11}$ Neither myeloablative nor non-myeloablative allogeneic stem cell transplants in order to exploit graft versus solid tumor effect did not result in an increase in the OS of patients with BC..$^{12,13}$

Recently, Martino et al. in an EBMT retrospective analysis, showed that adjuvant HDC with ASCT, in contrast with early studies ${ }^{14,15}$, is a safe procedure with a TRM (Transplant related mortality) that is, in more recent years, less than $1 \% .{ }^{16}$ This is consistent with what has been observed in modern prospective studies. ${ }^{17,18}$ Furthermore, in keeping with previous reports ${ }^{19-21}$, the long-term effects of HDC do not differ from those observed with conventional chemotherapy, in particular regarding the risk of secondary cancer. ${ }^{22,23}$

At the turn of the century, in view of early reports of randomized trials not showing a significant OS benefit of $\mathrm{HDC}^{24}$, this procedure was no longer considered a treatment option for the vast majority of medical oncologists. In the era of great expectations for targeted drugs, data from randomized studies demonstrating an OS benefit by HDC for high-risk breast cancer (HRBC) ${ }^{17,18}$, along with additional evidence of the benefit of intensified $\mathrm{CT}^{25}$ did not change this attitude. We, medical oncologists, all know that recurrence-free-survival (RFS) is a well-accepted parameter for evaluating the efficacy of various treatment modalities in the conventional setting. When it comes to HDC and ASCT almost all conventional oncologists focus on OS. Medical Oncologists would like to see a clearcut benefit on OS, in fact, one has to say that this is very peculiar and difficult to understand for supporters and users of HDC. I think the main reason for this approach is the limited use of HDC and ASCT by conventional oncologists, because HDC and ASCT require a special education at the centers that have experience and staff in this field. Most of the medical oncology trainees do not have exposure to and experience in this field.

This article is aimed at clarifying what happened over the years in this controversial field and whether today HDC with ASCT can be proposed in some sub-group of patients with BC.

\section{Adjuvant Setting}

Since the early 1990s, a total of 15 randomized trials comparing HDC with ASCT versus conventional chemotherapy (CCT) in HRBC have been conducted, ${ }^{11}$ being published in peer-reviewed journals. ${ }^{26}$ An advantage in RFS by HDC was reported in several of these studies while an OS benefit was observed, as previously underlined, in two modern European trials. ${ }^{17,18}$ The recent metaanalysis by Berry et al. ${ }^{19}$ has analyzed individual patient data from the 15 studies showing, in the whole population, a significant benefit of HDC in RFS but not in OS. In particular, of 6,210 patients with HRBC who were randomized in the 15 trials, HDC achieved a significant $13 \%$ reduction in the risk of recurrence (hazard ratio [HR], 0.87; 95\% $\mathrm{CI}, 0.81$ to 0.93 ) but no significant reduction in the risk of death (HR 0.94;95\%CI, 0.87 to 1.02;), after a median follow-up of 6 years. It is important to note that all HDC adjuvant studies included only patients with gross involvement of axillary lymph node (LN) at surgery (median: 12), regarded as a negative prognostic factor independently from other variables. 


\section{Metastatic Setting}

Seven phase III studies have been published in peer-reviewed journals, one subsequently updated in the form of a meeting abstract and one study has been reported as a meeting abstract. ${ }^{24}$ Most of these trials showed improved progression-free-survival (PFS) in the HDC arm, but only one an overall survival (OS) advantage ${ }^{24}$ Six randomized trials, including 866 metastatic breast cancer (MBC) patients, have been analyzed in the parallel metaanalysis of individual patient data. ${ }^{27}$ There was a statistically significant improvement in PFS (median, 11 v 8.3 months; HR, 0.76; $\mathrm{p}=0.001$ ) but no significant improvement in OS. The meta-analysis did not include two prospective studies involving 291 and 69 patients, respectively, and showing a potential survival benefit of HDC. ${ }^{24}$

The authors of the meta-analyse ${ }^{19,27}$ conclude that HDC with ASCT for HRBC and MBC does not produce sufficient benefit to be worthwhile, also in view of the toxicity of the procedure. Our personal view is that such an assumption is somehow questionable and deserves re-discussion if considering and critically reviewing the following points.

1. The prognosis of HRBC has changed very little in the past two decades; novel targeted therapies (i.e. trastuzumab and lapatinib) had a major impact only in the subset of patients with HER2-positive disease, accounting for about $25-30 \%$ of the whole BC population. Other molecular-targeted drugs, ie bevacizumab and PARP-inhibitors, did not fulfill their promise when tested in prospective trials. When considering the chemotherapeutic agents introduced in the last two decades, taxanes are the only ones to show additional benefit over conventional antracycline-based schedules. However, they have produced only limited survival advantage, if any, in patients at higher risk of relapse (i.e. $>$ 3 positive nodes) that represent the population of HDC studies. ${ }^{8,28}$

2. When defining an intensified CT program, it is crucial to consider regimens with a acceptable toxicity profile to avoid the morbidity and mortality observed in the early HDC studies. ${ }^{29}$ Over time HDC has become a safe and reasonably well-tolerated treatment modality with a mortality rate and quality-adjusted survival pa- rameters similar to CCT. ${ }^{8,17,30}$ To such an extent that it can be administered even in the outpatient setting ${ }^{31}$, ie when multiple cycles of higher (non-myeloablative) doses of CT followed by the infusion of blood stem cells after each cycle. This allows to safely increasing the intensity of anticancer therapy beyond that achievable with conventional dose, dose-dense or with single course of HDC. Such "high dose-density" approach, that is likely to provide a more effective strategy for minimizing residual tumor burden and reduce toxicity, is currently used in other malignancies. ${ }^{32}$ Cost savings associated with outpatient-based ASCT, feasible in BC patients undergoing less intensive $\mathrm{CT}$ regimens ${ }^{17}$, are relevant $^{33}$

3. HDC studies have been mostly conducted in the absence of biological information therefore including a proportion of patients with HER2positive tumor that we now know derive no benefit from higher doses of alkylating agents. ${ }^{34}$ As a matter of fact, the only study analysing the impact of HDC based on HER2 status demonstrated a clear superiority of HDC in the HER2negative population. ${ }^{34}$ In the meta-analysis of adjuvant studies ${ }^{19}$ an apparent OS benefit from HDC in patients harbouring HER2-negative tumors, was documented, being more marked in the triple-negative population (33\% reduction in the risk of death). Not all patients in those trials, which were included in this meta-analysis, had biomarker information, such as HER2 and hormone receptor $(\mathrm{HmR})$ status, and the metaanalysis was not able to address biomarkerbased subgroups of patients who would benefit from HDC. In fact, in the meta-analysis, OS data in the HER2-negative patients appear quite encouraging. The positive effect of HDC was even more marked in the triple-negative (TN) disease. ${ }^{8,19}$ Now, there is a big prospective randomized phase-III study is ongoing in The Netherlands comparing the efficacy of HDC and ASCT with conventional therapies in patients with Her2-negative and triple negative $\mathrm{BC}$.

Similarly, Gluz et al. ${ }^{35}$, found that the benefit of HDC was more evident in a basal-like phenotype (ER/PR negative, HER2 negative and basal cytokeratin-positive) and in grade 3 tu- 
mours. Other authors have speculated that patients with TN tumours are the most likely to receive a benefit from HDCT, because these cancers do not respond to endocrine therapy or other available targeted agents. The metastatic potential in TN BC is similar to that of other BC subtypes, but these tumors are associated with a shorter median time to relapse and death, as is also demonstrated in the small cohort of patients included by Martino et al. in the EBMT retrospective analysis. ${ }^{16}$

While only $27 \%$ of pts had HER 2 status available, Berry et al. conducted an additional (questionable) statistical evaluation, not often utilized in medical oncology, and conclude that "the triple-negative observation is likely to be spurious". ${ }^{19}$ A positive effect of HDC in HER2-negative population, particularly in triple-negative tumors, is biologically plausible and supported by clinical evidence. ${ }^{18,34,35} \mathrm{~A}$ meta-analysis of 10 randomized HRBC trials indicated that dosedense intensification results in a clear RFS and OS benefit for patients harbouring HER2-negative tumors. ${ }^{36}$

4. HDC regimens, in terms of chemotherapeutic agents and drug dosage, varied a lot among the randomized trials. ${ }^{19,27}$ This was also the case for the control arms; in some studies being radically different from what is considered CCT. ${ }^{14,29}$ The result of such heterogeneity is that control arms had greater dose-intensity than HDC arms in 5 of 15 HRBC studies. ${ }^{19}$ Over the ten trials in which the dose-intensity was greater in the HDC arm, a statistical significant improvement of OS was observed.

5. HDC does not seem to be detrimental to the chances of giving subsequent lines of $\mathrm{CT}$ in case of recurrence. ${ }^{26}$

6. RFS has been often considered an appropriate end-point for the acceptance of new drugs/treatment modalities in oncology clinical practice, as it takes into account the risk of death associated with treatment and is not influenced by old and newer treatments given after recurrence. ${ }^{15}$ Today, HDC with ASCT has become a safe treatment modality with mortality rate ${ }^{17,20,21}$ and quality-adjusted survival parameters ${ }^{30}$ similar to conventional therapies. TRM and morbidity has progressively decreased from the mid-1990s, possibly related to the widespread switch from bone marrow hematopoietic progenitor cells to peripheral blood stem cells ${ }^{37}$ and a better understanding of the whole procedure and supportive measures. ${ }^{38-41}$ Moreover, HDC regimens associated with a high TRM are no longer utilized.

The majority of the oncology community believes that HDC is no longer applicable now that we have entered the era of targeted therapies. Such a conclusion could be premature because the prognosis of high-risk $\mathrm{BC}$ has changed very little in the past two decades and particular novel targeted therapies have had an impact only in the subset of patients with BC overexpressing HER2. Moreover, in highrisk $\mathrm{BC}$, two large European studies demonstrated an OS benefit of HDC consistent with the benefit in the HER2 negative and triple-negative populations. ${ }^{17,18,35}$ In the adjuvant setting of $\mathrm{BC}$, a survival benefit, even if limited, still means thousands of women being cured. Whereas in a multivariate analysis which was published by Boudin $\mathrm{L}$ et al. HDC and ASCT did not change the prognostic value of immunohistochemical subtypes in MBC patients. ${ }^{42}$

In conclusion, we believe that HDC with ASCT may still represent a therapeutic option for wellinformed younger patients harbouring HER2negative tumors and having gross involvement of axillary LN (adjuvant setting) or highly chemosensitive disease (advanced setting). Therefore, this approach should be investigated further in welldesigned trials taking into account the clinical and biological information we currently have (and that are rapidly improving) and useful in selecting target patient populations who are more likely to benefit from CT given safely at higher than standard doses.

\section{REFERENCES}

1. Hryniuk W, Levine MN. Analysis of dose intensity for adjuvant chemotherapy trials in stage II breast cancer. J Clin Oncol 4: 1162-1170, 1986.

2. Demirer T, Buckner CD, Appelbaum FR, et al. Busulfan, cyclophosphamide and fractionated total body irradiation for autologous or syngeneic marrow transplantation for acute and chronic myelogenous leukemia: Phase I dose escalation of busulfan based on targeted plasma levels. Bone Marrow Transplant 17: 491-495, 1996. 
3. Demirer T, Buckner CD, Appelbaum FR, et al. Busulfan, cyclophosphamide and fractionated total body irradiation for allogeneic marrow transplantation in advanced acute and chronic myelogenous leukemia: Phase I dose escalation of busulfan based on targeted plasma levels Bone Marrow Transplant 17: 341-346, 1996.

4. Pedrazzoli P, Ferrante P, Kulekci A, et al. Autologous hematopoietic stem cell transplantation for breast cancer in Europe: critical evaluation of data from the European Group for Blood and Marrow Transplantation (EBMT) Registry 1990-1999. Bone Marrow Transplant 32: 489-494, 2003.

5. Pedrazzoli, P, Ledermann, JA, Lotz JP, et al. Group Author(s): European Grp Blood Marrow Transpla High dose chemotherapy with autologous hematopoietic stem cell support for solid tumors other than breast cancer in adults. Annal Oncol 17: 1479-1488, 2006

6. De Giorgi U, Rosti G, Slavin S, et al. Salvage high-dose chemotherapy for children with extragonadal germ-cell tumours. Group Author(s): European Grp Blood Marrow Transpla. Br J Cancer 93: 412-417, 2005.

7. T. Demirer. Response to 'Are there still reasons to believe that high-dose chemotherapy have a role in breast cancer management ? Letter to Editor. Bone Marrow Transplant 48: 305306, 2013.

8. Pedrazzoli P, Bregni M, Rosti G, et al. Autologous Stem Cell Transplantation: Is it still relevant in breast cancer. Breast Cancer Manag 2: 447-450, 2013.

9. Barkholt L, Bregni M, Remberger M, et al. On behalf of the EBMT Solid Tumour Working Party. Allogeneic haematopoietic stem cell transplantation for metastatic renal carcinoma in Europe. Annal Oncol 17: 1134-1140, 2006.

10. Aglietta M, Barkholt L, Carnevale Schianca F, et al. On behalf of the EBMT Solid Tumor Working Party. Reduced Intensity Allogeneic Hematopoietic Stem Cell Transplantation in Metastatic Colorectal Cancer as a Novel Adoptive Cell Therapy Approach. The European Group for Blood and Marrow Transplantation Experience. Biol Blood Marrow Transplant 15: 326335, 2009.

11. Peccatori J, Barkholt L, Demirer T, et al. on behalf of EBMT. Prognostic factors for survival in patients with advanced renal cell carcinoma undergoing nonmyeloablative allogeneic stem cell transplantation. Cancer 104: 2099-2103, 2005.

12. Demirer T, Barkholt L, Blaise D, et al. On behalf of the EBMT Solid Tumors Working Party. Transplantation of allogeneic hematopoietic stem cells: an emerging treatment modality for solid tumors. Nat Clin Pract Oncol 5: 256-267, 2008.

13. Ueno N T, Rizzo D, Demirer T, et al. Allogeneic hematopoietic cell transplantation for metastatic breast cancer. Bone Marrow Transplant 41: 537-545, 2008.

14. Bergh J, Wiklund T, Erikstein B, et al. Tailored fluorouracil, epirubicin, and cyclophosphamide compared with marrowsupported high-dose chemotherapy as adjuvant treatment for high-risk breastcancer: A randomised trial-Scandinavian Breast Group 9401 study. Lancet 356: 1384-1391, 2000.

15. Elfenbein GJ. Stem-cell transplantation for high-risk breast cancer. N Engl J Med 349: 80-82, 2003.
16. Martino M, Lanza F, Pavesi L, et al. on behalf of the EBMT Solid Tumors Working Party. High-dose chemotherapy and autologous hematopoietic stem cell transplantation as adjuvant treatmentin high-risk breast cancer: data from the EBMT Registry. Biol Blood Marrow Transplant, 22: 475-481, 2016.

17. Nitz UA, Mohrmann S, Fischer J, et al. Comparison of rapidly cycled tandem highdose chemotherapy plus peripheral-blood stem-cell support versus dose-dense conventional chemotherapy for adjuvant treatment of high-risk breast cancer: results of a multicentre phase III trial. Lancet 366: 1935-1944, 2005.

18. Rodenhuis S, Bontenbal M, van Hoesel QG, et al. Efficacy of high-dose alkylating chemotherapy in HER2/neu-negative breast cancer. Ann Oncol 17: 588-596, 2006.

19. Berry DA, Ueno NT, Johnson MM, et al. High-dose chemotherapy with autologous stem-cell support as adjuvant therapy in breast cancer: Overview of 15 randomized trials. J Clin Oncol 29: 3214-3223, 2011.

20. Pedrazzoli P, Martinelli G, Gianni AM, et al. Adjuvant high-dose chemotherapy with autologous hematopoietic stem cell support for high-risk primary breast cancer: results from the Italian national registry. Biol Blood Marrow Transplant 20: 501-506, 2014.

21. Martino M, Ballestrero A, Zambelli A, et al. Long-term survival in patients with metastatic breast cancer receiving intensified chemotherapy and stem cell rescue: data from the Italian registry. Bone Marrow Transplant 48: 414-8, 2013.

22. Kroger N, Damon L, Zander AR, et al. Secondary acute leukemia following mitoxantrone-based high-dose chemotherapy for primary breast cancer patients Group Author(s): European Grp Blood Marrow Translpl; German Adjuvant Breast Canc Study; Univ California San Francisco. Bone Marrow Transplant 32: 1153-1157, 2003.

23. Demirer T, Celebi H, Arat M, et al. Autoimmune thrombocytopenia in a patient with small cell lung cancer developing after chemotherapy and resolving following autologous peripheral blood stem cell transplantation. Bone Marrow Transplant 24: 335-337,1999.

24. Pedrazzoli P, Rosti G, Secondino S, et al. High-dose chemotherapy with autologous hematopoietic stem cell support for solid tumors in adults. Semin Hematol 44: 286-295, 2007.

25. Moebus V, Jackisch C, Lueck HJ, et al. Intense dose-dense sequential chemotherapy with epirubicin, paclitaxel, and cyclophosphamide compared with conventionally scheduled chemotherapy in high-risk primary breast cancer: mature results of an AGO phase III study. J Clin Oncol 28: 2874-2880, 2010.

26. Martino M, Bottini A, Rosti $G$, et al. Critical issues on highdose chemotherapy with autologous hematopoietic progenitor cell transplantation in breast cancer patients. Expert Opin Biol Ther 12: 1505-1515, 2012.

27. Berry DA, Ueno NT, Johnson MM, et al. High-dose chemotherapy with autologous hematopoietic stem-cell transplantation in metastatic breast cancer: overview of six randomized trials. J Clin Oncol 29: 3224-3231, 2011. 
28. Martin M, Pienkowski T, Mackey J, et al. Adjuvant docetaxel for node-positive breast cancer. N Engl J Med 352: 23022313, 2005.

29. Peters WP, Rosner GL, Vredenburgh JJ, et al. Prospective, randomized comparison of high dose chemotherapy with stem-cell support versus intermediate-dose chemotherapy after surgery and adjuvant chemotherapy in women with high risk primary breast cancer: A report of CALGB 9082, SWOG 9114, and NCIC MA-13. J Clin Oncol 23: 2191-2200, 2005.

30. Marino P, Roche H, Moatti JP, et al. High-dose chemotherapy for patients with high-risk breast cancer: a clinical and economic assessment using a quality-adjusted survival analysis. Am J Clin Oncol 31: 117-124, 2008.

31. Morabito F, Irrera G, Oliva E, et al. Infectious complications in breast cancer patients undergoing peripheral blood stem cell transplantation: a single center retrospective analysis towards outpatient strategy. Bone Marrow Transplant 28: 883-888, 2001.

32. Simonelli M, Rosti G, Banna GL, Pedrazzoli P. Intensified chemotherapy with stem-cell rescue in germ-cell tumors. Ann Oncol 23: 815-822, 2012.

33. Meisenberg BR, Ferran K, Hollenbach K, et al. Reduced charges and costs associated with outpatient autologous stem cell transplantation. Bone Marrow Transplant 21: 927932, 1998.

34. Nieto Y, Nawaz S, Jones RB, et al. Prognostic model for relapse after high-dose chemotherapy with autologous stem-cell transplantation for stage IV oligometastatic breast cancer. J Clin Oncol 20: 707-718, 2002.

35. Gluz O, Nitz UA, Harbeck N, et al. Triple-negative high-risk breast cancer derives particular benefit from dose intensification of adjuvant chemotherapy: results of WSG AM-01 trial. Ann Oncol 19: 861-870, 2008.

36. Bonilla L, Ben-Aharon I, Vidal L, et al. Dose-dense chemotherapy in nonmetastatic breast cancer: a systematic review and meta-analysis of randomized controlled trials. J Natl Cancer Inst 102: 1845-1854, 2010.

37. Siena S, Bregni M, Di Nicola M, et al. Durability of hematopoiesis following autografting with peripheral blood hematopoietic progenitors. Ann Oncol 5: 935-941, 1994.
38. Körbling M, Fliedner TM. The evolution of clinical periphera blood stem cell transplantation. Bone Marrow Transplant 17: 675-678, 1996

39. Demirer T, Petersen FB, Bensinger WI, et al. Autologous transplantation with peripheral blood stem cells collected after granulocyte colony-stimulating factor in patients with acute myelogenous leukemia. Bone Marrow Transplant 18: 29-34, 1996.

40. Demirer T, Gooley T, Buckner CD, et al. Influence of total nucleated cell dose from marrow harvests on outcome in patients with acute myelogenous leukemia undergoing autologous transplantation. Bone Marrow Transplant 15: 907-913, 1995.

41. Antman $\mathrm{KH}$, Rowlings PA, Vaughan WP, et al. High-dose chemotherapy with autologous hematopoietic stem-cell support for breast cancer in North America. J Clin Oncol 15: 1870-1879, 1997.

42. Boudin L, Chabannon C, Sfumato P et al. Immunohistochemical subtypes predict survival in metastatic breast cancer receiving high-dose chemotherapy with autologoushematopoietic stem cell transplantation. Eur J Cancer 57: 118-126, 2016.

\section{Correspondence}

Dr. Taner DEMIRER

Ankara Üniversitesi Tıp Fakültesi

Hematoloji Bilim Dalı

Cebeci Hastanesi

Cebeci, ANKARA / TURKEY

Tel: (+90-312) 4663717

email: drdemirer@gmail.com 